\title{
AS RELAÇÕES PÚBLICAS NA LITERATURA NORTE-AMERICANA CONTEMPORÂNEA: IMAGENS E PERSPECTIVAS NAS NARRATIVAS FICCIONAIS
}

\author{
LUÍZA DE ALMEIDA TAVARES GUIMARÃES \\ Universidade Católica de Santos. \\ Santos,São Paulo, Brasil. \\ email: luizaatg@hotmail.com \\ WELLINGTON TEIXEIRA LISBOA \\ Universidade Católica de Santos. \\ Santos,São Paulo, Brasil. \\ email:wtlisboa@yahoo.com.br
}


AS RELAÇÕES PÚBLICAS NA LITERATURA NORTE-AMERICANA CONTEMPORÂNEA: IMAGENS E PERSPECTIVAS NAS NARRATIVAS FICCIONAIS

Resumo: Esta investigação tem como objetivo analisar as representações das Relações Públicas na literatura norte-americana contemporânea, pontuando as vinculações entre este campo científico e sua abordagem na esfera literária. Apresentaremos um estudo de caso de uma obra que apresenta como um de seus personagens um relações-públicas. Este estudo demonstra que o processo de construção de conhecimento sobre as Relações Públicas também pode ocorrer de forma lúdica.

Palavras-chave: Imagens. Literatura. Relações Públicas. Sociedade.

RELACIONES PÚBLICAS EN LA LITERATURA NORTEAMERICANA CONTEMPORÁNEA: IMÁGENES Y PERSPECTIVAS NARRATIVAS DE FICCIÓN

Resumen: Esta investigación tiene como objetivo analizar las representaciones de las relaciones públicas en la literatura norteamericana contemporánea, destacando los vínculos entre este campo y de la esfera literaria. Nos centraremos en un estudio de caso acerca de una narrativa de ficción literaria como uno de sus personajes una persona de relaciones públicas. Esta investigación demuestra que el proceso de construcción de conocimiento sobre relaciones públicas también se puede producir de una manera lúdica.

Palabras clave: Imágenes. Literatura. Relaciones Públicas. Sociedad.

PUBLIC RELATIONS IN CONTEMPORARY AMERICAN LITERATURE: IMAGES AND PERSPECTIVES ON FICTIONAL NARRATIVES

Abstract: This research aims at analyzing the representations of public relations in contemporary American literature, pointing out the links between this field and his scientific approach in the literary sphere. Therefore, will be developed a study focused on the analysis of a book which has as one of its characters as a public relations. This research demonstrates that the process of building knowledge about PR can also be triggered, critical and interdisciplinary way. Keywords: Images. Literature. Public relations. Society. 


\section{INTRODUÇÃO}

A pergunta "O que é literatura?" pode confundir os mais leigos e incitar os especialistas sobre o assunto a pensar seriamente na resposta, uma vez que a literatura, em primeira análise, remete ao questionável sentido de que se configura como o óbvio, como afirma Roberto Acízelo de Souza (2004), em seu livro Teoria da Literatura. O motivo da complexidade em torno desta pergunta é simples, pois o conceito de literatura, como pontua este autor, se tornou difuso e culturalizado. Difuso porque a palavra literatura corresponde a inumeráveis significados e exemplos mais ou menos semelhantes entre si; culturalizado, pelo fato de corresponder a algo tão normal, ordinário e aceito comunitariamente, que parece não haver dúvida em sua definição (SOUZA, 2004). Acontece que a pergunta "O que é literatura?" encerra diversos problemas ao analisarmos cada uma das explicações que já foram e ainda são propostas no decurso das investigações e reflexões sobre esse tema.

É possível definirmos literatura como tudo que foi impresso, uma obra escrita, um romance, um livro de poesias, ou até mesmo nos restringir aos "grandes livros", ou melhor, aqueles que são historicamente considerados clássicos pela comunidade científica e especialistas no assunto. Entretanto, não haveria um problema nessa vertente de explicação? Significa que, se uma obra não tiver grande repercussão, em termos de público e/ou por suas qualidades estéticas, não se define como literatura? Há obras que circulam no mundo inteiro, mas não são literatura, e outras que podem ser pouco conhecidas, mas são fiéis exemplos de linguagem e construção literária, o que nos leva a apontar que esta definição não convém, diretamente, à presente investigação. Outra forma de tentar expressar em palavras o conceito de literatura leva-nos a entendê-la como a escrita "imaginativa" (EAGLETON, 1983), ou seja, a ficção. Todavia, como pontua Eagleton (1983), não seria um equívoco colocar na mesma categoria de "imaginativo" as obras de Shakespeare e os sermões de John Donne?' Ou, então, obras de Bunyan² e O Leviatã, de Thomas Hobbes? Aconte-

1 John Donne (1572-1631) foi um poeta jacobino inglês e o maior representante dos poetas metafísicos da época. Sua obra apresenta estilo sensual e realista, com recorrência a metáforas e linguagem vibrante.

2 John Bunyan (1628-1688) foi um escritor cristão, pregador e autor de The Pilgrim's Pro- 
ce que a distinção entre fato e ficção também não se encaixa na presente investigação, que considera que a literatura pode se fundar, em grande parte, na escrita criativa, ou imaginativa, como citado acima, mas também inclui margem considerável de escrita factual, afinal, não poderíamos excluir da literatura as obras de história, filosofia e ciências naturais, por exemplo (SOUZA, 2004).

Com relação a esta questão, Eagleton (1983, p. 14-15) faz a seguinte ponderação.

Não existe uma "essência" da literatura. [...] Qualquer coisa pode ser literatura, e qualquer coisa que é considerada literatura, inalterável e inquestionável - Shakespeare, por exemplo -, pode deixar de sê-lo. Qualquer idéia de que o estudo da literatura é o estudo de uma entidade estável e bem definida pode ser abandonada como uma quimera. Alguns tipos de ficção são literatura, outros não; parte da literatura é ficcional, e parte não é; a literatura pode se preocupar consigo mesma no que tange ao aspecto verbal, mas muita retórica elaborada não é literatura. [...] uma obra pode ser considerada como filosofia num século, e como literatura no século seguinte.

Para Antônio Cândido (2002), a literatura, assim como toda arte, é uma transposição do real para o ilusório, por meio de uma estilização formal da linguagem. Em seu texto A literatura e a formação do homem, Cândido (2002) identifica três funções exercidas pela literatura, o que o leva a pensar que, no seu conjunto, essas funções correspondem à "função humanizadora da literatura". A primeira função discriminada por este autor diz respeito à capacidade e necessidade que tem o homem de fantasiar, criando novelas, contos, narrativas de amor, perspectivando o futuro e recriando as relações entre os homens e seus complexos vínculos sociais. Dessa necessidade de criação e imaginação, cujas bases se situam, em geral, na realidade cotidiana e nos aspectos subjetivos, deriva a dimensão psicológica da literatura.

É essa vinculação da criação e da fantasia às múltiplas dimensões do real que, na concepção de Cândido (2002), proporciona a segunda função da literatura, a formadora. Significa dizer que a literatura atua como instrumento de educação, de formação do homem, expressando tanto as ideologias que são dominantes em certos grupos sociais quanto aquelas que são marginaliza-

gress (O Peregrino), uma das obras cristãs mais conhecida de todos os tempos. 
das ou contra-hegemônicas. Assim, ao expressar a multiplicidade de enredos, discursos e poderes que transitam nos cotidianos plurais, a literatura fornece subsídios para que o homem construa, inclusive de forma lúdica e crítica, as suas opiniões e interrogações sobre os contextos que lhes são envolventes. Representa um artifício intelectual para o enfrentamento de situações diversas na vida cotidiana. A terceira função sublinhada por Antônio Cândido, articulada às demais, refere-se à função social, que possibilita ao indivíduo o reconhecimento da realidade que o cerca, a partir da identificação de certos elementos, ambientações e personagens que são comuns às suas próprias experiências pessoais, no mundo do qual participa. Essa função, vale pontuar, desencadeia um processo de integração, envolvimento e constituição identitária, sobretudo no que toca ao universo geracional, de classe social, gênero, hábitos e estilos de vida, entre outros.

Com relação a este ponto, é interessante pensarmos que houve épocas em que o valor de uma obra era medido conforme a realidade social que ela demonstrava, mas também houve o tempo em que se revelou total oposição a esse entendimento. A integridade da obra não permite, contudo, a primazia de nenhuma dessas visões. O social, que funciona como um fator externo, tem sua importância na obra literária, mas apenas como constituição da sua estrutura (CÂNDIDO, 1985).

Com efeito, todos sabemos que a literatura, como fenômeno de civilização, depende, para se construir e caracterizar, do entrelaçamento de vários fatores sociais. Mas, daí a determinar se eles interferem diretamente nas características essenciais de determinada obra, vai um abismo, nem sempre transpostos com felicidade (CÂNDIDO, 1985, p. 12).

Dessa forma, o contexto social, embora não menos relevante, se torna apenas um dos aspectos que interferem na produção da obra literária, tal como muitos outros também influenciam, como psicológicos, religiosos, linguísticos, culturais, políticos, entre outros fatores, se é que é possível separar essas variáveis. Ademais, como sublinha Cândido (1985), o autor, também e em certa medida, consegue filtrar muitos desses intervenientes, conferindo significados múltiplos ao texto produzido. Dessa linha de entendimento emergem, por um lado, questões alusivas à literatura como produto e reflexo do meio em que foi gestada e, por outro, indagações acerca da influência da obra literária sobre o meio social, no que diz respeito à transformação de percepções e mentalida- 
des. Ambos os vieses epistemológicos, por certo, caracterizam-se como bastante complexos e de uma abrangência que extravasa, na sua totalidade, os limites de compreensão na investigação que ora se apresenta.

Por sua vez, ao analisarmos o campo das Relações Públicas, tratamos diretamente de opinião pública, afinal esta profissão existe pela demanda gerada pelas opiniões partilhadas na esfera pública. A partir do momento histórico que consumidores, funcionários, comunidades passaram a reivindicar seus direitos e demonstrar que tinham voz e poder para colocar as organizações em situações problemáticas, comprometendo o objetivo-fim das empresas, o lucro, consolidou-se a base para o nascimento das Relações Públicas na modernidade, a princípio nos Estados Unidos (KUNSCH, 2003; MOURA, 2008; FERRARI, 2009). Os públicos, que são agrupamentos humanos que partilham interesses em relação à organização (FRANÇA, 2004), passaram a exigir a possibilidade de diálogo, de informações e comunicação sistemática. Se, antes, as corporações, de forma inconsequente, se preocupavam apenas com o lucro, hoje, sabe-se que o faturamento também emana de uma identidade e imagem favorável, inclusive porque, do contrário, qualquer empresa está fadada a desaparecer (FORTES, 2003).

Nesse sentido, é um equívoco relacionar as atividades dos relações-públicas apenas ao cerimonial e realização de eventos, como historicamente vem se concebendo em múltiplas partes do mundo (KUNSCH, 2003), seu objetivo primordial é o bom relacionamento da organização com seus diversos públicos, valendo-se de planejamento estratégico da comunicação para efetivar os vínculos. James Grunig (2003), um dos mais notórios autores norte-americanos sobre as Relações Públicas, refere que o profissional desta área planeja, implanta e desenvolve o processo da comunicação institucional, ordenando os relacionamentos da organização com os públicos de interação. Na sua acepção, este trabalho de manutenção dos vínculos comunicacionais, com vistas ao atendimento das expectativas e interesses tanto das organizações quanto dos públicos, gera a credibilidade institucional e de seus produtos e serviços no mercado. É nesta perspectiva que este autor evidencia o caráter multifuncional e estratégico da atividade de Relações Públicas. Mas o conjunto de aptidões e funções próprias das Relações Públicas, campo científico e profissional relativamente novo no mundo, é devidamente descrito nas narrativas ficcionais literárias contemporâneas? Quais as imagens das Relações Públicas que podem 
ser captadas a partir da análise de personagens literários caracterizados como profissionais desta área?

A presente investigação tem como objetivo analisar as representações das Relações Públicas na literatura norte-americana contemporânea, considerando-se que os Estados Unidos são o país onde nasceu esta profissão e onde, na atualidade, ela mais se desenvolve (GRUNIG, 2003; 2011a). São descrições que correspondem às definições científicas desta área, na complexidade e importância que lhe é inerente? Ou são reproduzidas imagens e percepções reducionistas sobre essa profissão, limitando-a a atividades como eventos e cerimoniais, ou mesmo confundindo-a com o marketing ou publicidade e propaganda? Quais as similitudes e incongruências entre a caracterização das Relações Públicas na produção literária norte-americana e o arcabouço teórico que vem se legitimando neste campo de conhecimento? Com base nesses questionamentos, que estruturam o objetivo desta pesquisa, desenvolvemos um estudo de caso focado na análise das representações em torno do personagem Noah Gardner, um relações-públicas que compõe o enredo da obra A Janela de Overton, best-seller de autoria de Glenn Beck³.

\section{A JANELA DE OVERTON: RELAÇÕES PÚBLICAS A SERVIÇO DE QUEM?}

A Janela de Overton, que é apenas o primeiro livro de uma série, nos transporta para o cenário norte-americano, onde uma grande conspiração está sendo cuidadosamente planejada há quase 100 anos. Logo de início, somos apresentados aos personagens principais, Noah Gardner, Arthur Gardner e Molly Ross. Noah é um executivo de Relações Públicas bem-sucedido que trabalha na empresa Doyle \& Merchant, especializada em encobrir e resolver as piores crises de seus clientes.

3 Beck é comentarista político, apresentador de rádio, vlogger, autor, empresário e ex-apresentador de televisão. Escreveu seis livros considerados pelo New York Times como best-seller e é fundador e CEO da Mercury Radio Arts, uma empresa de produção multimídia, através da qual produz conteúdo para rádio, televisão, palcos e internet. Ele defende em seus programas e produções os princípios do liberalismo político-econômico, responsabilidade individual, os valores clássicos norte-americanos, a cultura judaico-cristã e prega a aderência aos princípios da Constituição dos Estados Unidos. 
Noah vive às sombras de seu pai, Arthur Gardner, o criador e presidente da empresa, uma das pessoas mais habilidosas e influentes daquele país. Molly trabalha como funcionária temporária e é uma mulher engajada em ideais políticos, que deseja trazer de volta aos Estados Unidos a glória e a ética que um dia tiveram. Ela acredita que uma conspiração se esconde por trás das paredes da Doyle \& Merchant. No decorrer do livro, é revelado que esta empresa de Relações Públicas é responsável por elaborar uma conspiração que visa influenciar cada um dos departamentos políticos do governo norte-americano, desde o setor do turismo até o da educação, para que as pessoas sintam que precisam ser controladas, para terem segurança, ficando mais fácil de implantar a ditadura naquele país. Todas essas ações são implementadas pelo departamento de Relações Públicas e pelo próprio Arthur Gardner, envolvendo estratégias de comunicação, publicidade, marketing para transformar a população em dependentes do sistema de governo a ser implementado.

O livro é dividido, até certo ponto, em três focos distintos. A relação de Noah e Molly, que nos passa a ideia de um possível romance; a conspiração, que é descoberta ao longo da obra; e a intromissão de um agente do FBI em um suposto atentado terrorista. No decorrer do livro estes três pontos se interligam até chegar o momento em que Noah, o relações-públicas, deve decidir se segue seus próprios ideais, priorizando a ética em sua atuação profissional, ou herda o império de seu pai, construído com base na conspiração em torno do governo dos Estados Unidos. Por fim, mostra-se que Noah toma sua decisão e segue Molly em sua jornada para destruir o plano de conspiração. Entretanto, ao ser capturado e ameaçado de morte, Noah concorda em ajudar nas campanhas de seu pai para a reconstrução do governo, mas, secretamente, recebe mensagens de Molly, com quem planeja destruir aquela conspiração, de dentro para fora, agindo como um agente duplo infiltrado. $O$ livro termina deixando brechas para uma possível continuação, em formato de série.

\section{RELAÇÕES PÚBLICAS NA LITERATURA: IMAGENS E PERSPECTIVAS}

Nesta etapa da investigação, analisaremos a referida obra à luz de diversas teorias das Relações Públicas. O propósito de aprender de forma lúdica as Relações Públicas, por meio da ficção literária, não se revela tarefa fácil, pois são poucos os livros ficcionais que abordam esse campo científico e profissional 
da Comunicação Social. Entretanto, após a leitura de uma obra como A Janela de Overton, é possível identificar a dificuldade (e os inúmeros equívocos) em definir esta profissão, sobretudo por parte de autores que, diretamente, não têm qualquer vínculo com esta área. Mas é importante pontuar que toda obra, mesmo fictícia, é regada por pesquisas e estudos, muitas vezes focando os contextos sociais e históricos (SOUZA, 2004), o que também nos permite apresentar pontos em comum entre a forma como Glenn Beck concebe as Relações Públicas e como, de fato, este campo é sistematizado teoricamente. São esses eixos, similares e incoerentes, que serão tratados neste estudo.

Para iniciarmos esta análise, recorremos a James E. Grunig (2011b, p. 34, grifo do autor), que define as Relações Públicas como

[...] a administração da comunicação entre uma organização e seus públicos [...] Os profissionais de Relações Públicas planejam e executam a comunicação para a organização na sua totalidade, ou apóiam partes da organização a desenvolverem a sua comunicação. [...] no nível gerencial os profissionais de Relações Públicas elaboram programas de comunicação para se comunicar com os públicos.

Cicillia Peruzzo (2009, p. 159), por sua vez, caracteriza as Relações Públicas como uma atividade que visa sempre estabelecer, entre a organização e seus públicos, um bom relacionamento. A profissão tem como foco a satisfação não apenas das instituições, auxiliando-as em seu sucesso, mas dos públicos que as influenciam. De acordo com Peruzzo (2009), as Relações Públicas atuam na garantia da prosperidade e longevidade da organização, contribuindo com uma boa reputação, imagem e com a aceitação pública da empresa. A Associação Brasileira de Relações Públicas, seção São Paulo (2013), também afirma que esta profissão tem como finalidade a compreensão mútua entre a instituição, pública ou privada, e os grupos de pessoas aos quais está ligada. Os públicos são os mais diversos, desde o consumidor até a comunidade com a qual se envolve a instituição, os fornecedores, funcionários, governos, mídia, e até mesmo grupos que estejam, por motivos específicos, contra a organização, sendo que o relações-públicas deve elaborar um plano de comunicação que atinja os objetivos da empresa e, ao mesmo tempo, satisfaça os interesses e anseios de seus públicos de influência.

Em A Janela de Overton, logo no início da obra, uma definição da profissão 
expressa pela personagem Molly Ross nos chama a atenção: "Tudo que vocês, relações públicas (sic), sabem fazer é ganhar a vida mentindo. Para vocês a verdade não passa de uma boa história" (BECK, 2011, p. 28). Ainda no mesmo parágrafo, tal afirmação é justificada pelo próprio profissional de Relações Públicas, Noah Gardner:

Ele sentiu um impulso automático de elaborar uma defesa, mas [...] Em certo sentido ela estava absolutamente certa. À bem da verdade, o que ela acabara de dizer [...] era a mais perfeita tradução que um leigo poderia dar da declaração de princípios e objetivos da empresa (BECK, 2011, p. 28).

Ao longo do livro, essa imagem do relações-públicas como profissional inescrupuloso e antiético se fortalece pelas palavras do autor, através de seus personagens. "A discussão certo versus errado não era importante para o resultado final [...]. Guerra, paz e política sempre tinham feito parte do negócio, porque era aí que estava o dinheiro grosso" (BECK, 2011, p. 69). Toda a obra encontra-se repleta de exemplos como esses, mostrando um profissional que se utiliza de técnicas e estratégias para mentir, deturpar a verdade e livrar os culpados de suas sentenças, mesmo a custos de mentiras e sabotagens. Noah Gardner, personagem principal do livro, ao falar de si, afirma que "Quem ganha a vida mentindo, às vezes, não consegue enxergar a verdade nem mesmo se ela estiver bem na sua frente" (BECK, 2011, p. 341). No campo científico, porém, Waldyr Gutierrez Fortes (2009, p. 154, grifo do autor) comenta a importância da ética e da estética na profissão de Relações Públicas.

A ética sustenta-se na busca da legitimidade da ação organizacional e no que diz respeito ao discurso do profissional, na informação para os públicos e na sua liberdade de decisão. Quanto à estética, a definição operacional da atividade de relações públicas desde há muito prescreve que, antes de justificar ou explica as ações organizacionais, se deve "arrumar a casa", pondo em prática políticas organizacionais justas. A atividade de relações públicas, sem seu sentido abstrato, é ética e estética, pois visa uma sociedade harmônica.

O profissional de Relações Públicas, assim, deve atuar como conselheiro da ética dentro da organização para a qual trabalha, tal como ressalta Grunig 
(2011a), ao considerar essa função gerencial como responsável pela introdução de valores morais e responsabilidade social nas tomadas de decisão. Na concepção deste autor, em consonância à linha de raciocínio de Maria Aparecida Ferrari (2009), é necessário desenvolver programas de comunicação interna e externa regidos pela ética e em prol da democracia. Nessa perspectiva, Grunig (2011b, p. 112) define alguns estágios para medir se as ações de uma empresa estão sendo tomadas com base na ética. De início, é necessário fazer uma pergunta: "se o indivíduo está agindo com base somente na razão, e não por conta de influência política, monetária, ou por mero interesse próprio". Em seguida, é preciso pensar se "Esta organização aceitaria essa decisão se estivesse do outro lado". No terceiro estágio, "Pede à organização para considerar seu dever, suas intenções e dignidade e respeito por ela própria, por seus públicos e pela sociedade." e, por fim, "Requer a comunicação simétrica para obter resultados éticos no processo decisório".

Na leitura da obra analisada, ao ser citado o sistema de casas lotéricas nos Estados Unidos, Noah Gardner comenta que "[...] era graças aos truques e trapaças do pessoal de relações públicas que as pessoas continuavam acreditando no impossível, ano após ano" (BECK, 2011, p. 53). Em uma de suas falas, o mesmo personagem ainda denuncia, para um grande grupo de pessoas num bar, as mentiras na empresa na qual trabalha, sem se incomodar com a repercussão de seu discurso: "Vejam só, o lugar em que eu trabalho é onde todos os segredos são revelados, porque, para que a gente possa esconder seus segredos primeiro, eles precisam nos contar tudo" (BECK, 2011, p. 107). Esta afirmação contradiz a essência da profissão de Relações Públicas, que, para Waldemar Luiz Kunsch, tem a ver com a declaração de princípios que Ivy Lee publicou em 1906: "Nosso trabalho é feito às claras [...], nosso assunto é exato [...], nosso plano é divulgar com absoluta franqueza" (WEY, 1986, p. 31 apud KUNSCH, L. W., 2009, p. 9).

A empresa Doyle \& Merchant, além de antiética, também trata a população norte-americana como massa acrítica, um aglomerado de pessoas sem diferenciais, características ou anseios. Neste caso, seria um público fácil de manipular e controlar, "[...] as massas, os lemingues que mal conseguem ter a inteligência suficiente para seguir vivendo às cegas, sem objeções, resistência ou protesto" (BECK, 2011, p. 255), nas palavras de Arthur Gardner, funda- 
dor e presidente da empresa de Relações Públicas. Esta visão deturpada de público aparece algumas vezes ao longo da obra e surpreende a cada palavra. Nas primeiras páginas, durante uma reunião secreta, Arthur é questionado em relação às suas ações e em como elas surtiriam efeitos entre a população. Categoricamente, este personagem faz a seguinte declaração:

O povo perdeu a coragem de acreditar: Abriu mão de sua capacidade de pensar. As pessoas já não conseguem sequer formar suas próprias opiniões, apenas absorvem opiniões [...]. Os pensamentos das pessoas são fabricados por gente como eu. [...] Se as pessoas forem simplesmente enganadas, há sempre a chance de um dia acordarem e se rebelarem contra o crime. Mas nós não as fazemos mudar de ideia. Nós mudamos a verdade. [...] Nós alavancamos suas esperanças e alimentamos seus medos, e, depois que elas acreditam, são nossas para sempre. Não vai haver revolução, apenas um salto adiante, breve e um tanto quanto chocante, rumo à evolução social. Vamos restaurar a ordem natural das coisas, e depois haverá apenas paz e aceitação entre as massas (BECK, 2011, p. 45-46, grifo nosso).

Em relação ao conceito de público, Margarida Kunsch (2009) cita Grunig e Hunt (1983), que opinam sobre a noção de público geral, comentando que tal afirmação é uma impossibilidade lógica, afinal os públicos são obrigatoriamente específicos, que têm um problema em comum. Para esclarecer melhor o significado de público como diferente de massa, Fábio França (2004) explica a conceituação de massa como um agrupamento de pessoas sem contiguidade espacial, anônima e sem organização. Ao contrário, o público é um agrupamento espontâneo e organizado, com abundância de informações, que analisa uma controvérsia utilizando-se de opiniões múltiplas em relação à que medida deve ser tomada para que haja uma solução para seus problemas. $O$ público, como sublinha França (2004), tem a habilidade de discussão e debate por meio da interação social ou pelos veículos de comunicação, expressando uma decisão ou opinião coletiva que permite ação.

Fábio França (2004) explica que é necessário estudar a cultura de cada público, seus valores, crenças e tradições, que influenciam em seu comportamento, sendo que cada um desses aspectos precisa ser analisado e compreendido para o mútuo entendimento e conciliação de objetivos entre os públicos e a organização, em todos os seus níveis. Portanto, a definição de massa é contrária a essa 
linha de raciocínio, sem respeitar as especificidades de cada público. Outro ponto observado na narrativa ficcional são os conceitos de identidade organizacional, políticas e programas voltados ao público interno. A identidade organizacional é considerada a essência da empresa, seus valores e crenças, e é exatamente esse universo de significações e práticas que faz com que ela se diferencie de outras instituições. A identidade é relativamente estável ao longo do tempo, mantendo ligações íntimas entre o presente, o passado e o futuro (MARCHIORI, 2006; FERRARI, 2009). Os valores da empresa tornam-se, logo, parte de sua identidade e têm a função de vincular as pessoas, "O conhecimento dos valores de uma organização, portanto, permite predizer o seu funcionamento e o comportamento organizacional de seus membros" (FERRARI, 2009, p. 252).

Neste âmbito, os relações-públicas, por meio da gestão dos processos comunicacionais, visam criar um clima agradável no ambiente de trabalho, partindo do princípio de que o trabalhador satisfeito dedica-se com mais diligência e tem melhor rendimento em sua função, além de estimular os outros que o cercam (PERUZZO, 2009). No livro de Glenn Beck, a identidade organizacional da empresa Doyle $\&$ Merchant é descrita ao longo de várias páginas como extremamente rígida e com marcas próprias da personalidade do presidente, Arthur Gardner, que tem postura autoritária.

Na Doyle \& Merchant não eram permitidos relógios, nem nas paredes nem nos pulsos. [...] Não se tratava apenas de um simples local de trabalho. Ao longo das décadas o escritório tinha se metamorfoseado [...] de acordo com o que passava no interior do cérebro do velho: era guarnecido de todas as coisas de que ele gostava e não tinha espaço algum às coisas de que ele não gostava. Às vezes, essas esquisitices eram fruto de um impulso ou de um arroubo, outras vezes surgiam após longas deliberações, mas, depois que o rei Arthur tomava uma decisão, ele jamais, nunca, em hipótese alguma, mudava de ideia. (BECK, 2011, p. 51, grifo nosso).

Posteriormente, é dito que, em 1978, uma funcionária consultou seu relógio de pulso durante um discurso de Arthur e, no dia seguinte, já não trabalhava na Doyle \& Merchant. As políticas internas da empresa são claramente elucidadas na seguinte frase: "Graças à benevolência de Sua Alteza [Arthur Gardner], a existência de janelas continuou sendo tolerada, mas o acesso a qualquer vista do mundo exterior passou a ser limitado exclusivamente aos escritórios exe- 
cutivos" (BECK, 2011, p. 52). Logo, a cultura e identidade desta organização são extremamente rígidas, hierarquizadas, dependentes da personificação e das mais estranhas manias de seu presidente, citado como "rei Arthur". Esse posicionamento revela que o funcionário pouco pode opinar e não tem poder algum nas tomadas de decisão ou reuniões da organização, contrastando com os postulados teóricos sistematizados por Grunig (2011a, p. 67), na “Teoria Geral da Excelência em Relações Públicas”, segundo a qual "Uma estrutura orgânica significa que funcionários em toda a organização estão habilitados a participar das tomadas de decisão e que o processo decisório não está centrado no topo da organização".

Os relações-públicas, como dito anteriormente, são responsáveis por planejar e elaborar ações de comunicação que visam atingir objetivos e sondar o ambiente para que sempre haja uma solução para problemas futuros. Esse profissional "identifica assuntos emergentes potenciais ao analisar no ambiente os públicos que possivelmente sofrerão as consequências das decisões organizacionais" (GRUNIG, 2011b, p. 21). É de competência dos relações-públicas avaliar os processos políticos internos a fim de detectar quaisquer mudanças que possam se tornar uma crise, entretanto, "no momento que as consequências de uma decisão gerencial chegam à mídia e se tornam de domínio público, é tarde demais para influenciar a decisão [...] só se controlam os danos" (GRUNIG, 2011b, p. 86).

Neste ponto, no terceiro capítulo de A Janela de Overton, um documento de extrema importância vaza do governo dos EUA para as páginas do Post, jornal americano de grande repercussão, causando impacto entre a população e junto a grupos humanitários. No mesmo dia, alguns políticos e proprietários de grandes corporações convocam uma reunião com a Doyle \& Merchant, para que esta empresa de Relações Públicas resolvesse a crise. Arthur, durante a reunião, comenta que alguém levará a culpa pelo incidente e que não era necessário se preocupar com a repercussão da notícia. Em vez de resolver uma crise da forma como alertado por alguns autores das Relações Públicas, com ética e visando sempre esclarecer toda a verdade, comprometendo-se em reverter a situação, a Doyle \& Merchant apenas encobre, com mentiras, a situação e atribui culpa a outras pessoas. Atitudes empresariais como essa já foram alvo de críticas quando, por exemplo, Ivy Lee referiu à Rockefeller: "Diga 
sempre a verdade, porque mais cedo ou mais tarde o público vai descobrir de qualquer forma. E se o público não gostar do que você está fazendo, mude suas políticas e ponha-as em acordo com o que o público deseja" (KUNSCH, L. W., 2009, p. 10).

Cabe-nos também pontuar que é possível identificar pontos em comum entre o livro A Janela de Overton e as teorias das Relações Públicas. Esta obra fictícia apresenta um relações-públicas reportando-se diretamente à alta administração, tendo assim a liberdade de exercer suas ações e estratégias apenas com o aval do presidente e fundador da empresa. Como cita Grunig (2011a, p. 54), "o alto executivo de relações públicas é membro da coalizão dominante da organização ou se reporta diretamente aos diretores executivos que pertencem a ela", pois, dessa forma, é possível que "o profissional tenha liberdade para tomar decisões a respeito dos problemas de relações públicas sem excessivamente necessitar de autorização dos demais dirigentes da organização". Grunig (2011a) ainda pontua a importância desse aspecto para o desenvolvimento das Relações Públicas excelentes, já que muitas empresas vinculam este profissional apenas como assessor de outros departamentos. É certo, pois, que analisar e projetar a identidade e a imagem organizacional requer do relações-públicas participação direta nas dinâmicas organizacionais, desde a proximidade com as relações sociais entrelaçadas no nível operacional até as decisões de projetos no alto escalão da instituição.

A obra de Glenn Beck também surpreende ao referir o nome de uma conhecida personalidade das Relações Públicas, Edward Louis Bernays, o primeiro professor desta área em uma universidade e autor da primeira obra sobre este campo de conhecimento, Crystallizing public opinion (1923). Em A Janela de Overton, Noah explica como Arthur se envolveu com as Relações Públicas, revelando que teve como mentor Bernays:

Ele estava estudando antropologia em Oxford quando conheceu um homem chamado Edward Bernays - sobrinho e admirador de Sigmund Freud [...] - e o Sr. Bernays precisava de sangue novo, alguém com as habilidades do meu pai para injetar gás no ramo de atividade que ele tinha inventado décadas antes (BECK, 2011, p. 134).

O fato de um nome conhecido no campo teórico das Relações Públicas aparecer nesta obra fictícia demonstra a preocupação do autor em pesquisar sobre 
a profissão e ter, ao menos, alguma base para escrever sobre esta área. Por fim, A Janela de Overton trata de uma grande conspiração para uma mudança definitiva de governo nos Estados Unidos, sendo que Arthur Gardner lidera essa conspiração, articulada por sua empresa de Relações Públicas há quase uma década. As técnicas, estratégias e planos de ação utilizados pelos personagens se assemelham, na sua estrutura, a programas e modelos de comunicação analisados por teóricos das Relações Públicas. Contudo, nesta narrativa ficcional, os programas objetivam a manipulação da opinião pública, e não sua conscientização e um relacionamento de mão-dupla, como defende o aporte teórico das Relações Públicas (FORTES, 2003; KUNSCH, 2009; FERRARI, 2009; GRUNIG, 2011a).

No décimo nono capítulo, Noah e Molly invadem a sala de reuniões e descobrem o grande plano de ação que a Doyle \& Merchant está elaborando há anos. Ao analisarem os dados da reunião, deparam-se com um cronograma com objetivos a serem cumpridos e outros já alcançados, tais como: centralizar os poderes nas mãos do Poder Executivo; na educação, reforçar a dependência ideológica; difundir uma visão de mundo retrograda e extremista à população; preparar contingências, sistema e pessoal para prisão/relocação/detenção. Alguns desses programas de ação, subsidiados por estratégias de Relações Públicas, estendiam-se por poucos anos, mas outros abarcavam mais de um século. A base dos planos de conspiração apresentados nesta obra fictícia assemelhase, em certos aspectos, à estrutura dos planos de comunicação referendados nas teorias das Relações Públicas, como no Modelo PII: preparação, implementação e impacto e nos modelos de curta duração e contínuo. O modelo PII, proposto por Cutlip, Center e Broom (1985), constitui-se de três etapas de avaliação, em diferentes níveis do planejamento, sendo que cada etapa serve para aumentar a eficácia do projeto.

O primeiro estágio consiste na elaboração do plano de comunicação. [...] determinação de objetivos e metas [...] que, consequentemente, possibilitarão a avaliação dos resultados trazidos pelo plano. $O$ estágio seguinte prevê avaliação do processo de implementação e execução do programa e considera as táticas utilizadas [...] A última fase, por sua vez, refere-se à avaliação de retorno (feedback gerado pelo programa) e de resultado (impacto, efeito no público ao qual o programa se destinava), aspectos aqui considerados como mensuração (CUTLIP; CENTER; BROOM, 1985 apud LOPES; GRANDI, 2009, p. 395-396). 
Já os modelos de curta duração e contínuo são apresentados por Tom Watson (2001), citado por Lopes e Grandi (2009). O primeiro modelo sugere que a avaliação dos resultados de comunicação seja realizada, em curto prazo, por meio do alcance de metas e objetivos atingidos, ou não. Watson (2001) propõe também o modelo contínuo, que busca verificar os resultados da comunicação e seu impacto sobre os públicos, em longo prazo, sendo recomendável a avaliação ininterrupta dos programas. O plano de conspiração encontrado pelos personagens Noah e Molly, na Doyle \& Merchant, apresentava etapas discriminadas com exatidão, suas formas de avaliação e impacto na opinião pública, tal como se verifica num planejamento estratégico de Relações Públicas, não obstante a sua essência diferenciada.

\section{CONSIDERAÇÕES FINAIS}

A análise da obra A Janela de Overton nos permite identificar uma evidente distorção interpretativa, no campo literário, sobre as funções, objetivos, competências e filosofia das Relações Públicas. As distorções existentes são surpreendentes e preocupantes: profissional antiético e focado somente no lucro a todo custo; públicos tratados como massa irracional, amorfa e manipulável, sem importância para a empresa e para o país, bem a gosto do pensamento frankfurtiano; crises empresariais sendo resolvidas com mentiras e, como se diz popularmente, "empurradas para debaixo do tapete"; desrespeito aos princípios e valores democráticos; funcionários sendo tratados, hierarquicamente, como simples executores de tarefas, sem participação nas decisões institucionais e sem possibilidade de diálogo, contrariamente ao que se vislumbra na perspectiva teórica da via de mão-dupla na comunicação (KUNSCH, 2009; GRUNIG, 2011a).

Todos esses aspectos, que se contrapõem aos fundamentos epistemológicos deste campo científico, ainda se agravam ao lembrarmos que tratamos aqui de uma obra fictícia de autor dos Estados Unidos, país onde nasceram e se desenvolveram as Relações Públicas e onde, atualmente, essa ciência apresenta nível de reconhecimento mundial. Sendo assim, parece-nos que o profissional desta área ainda enfrenta, nos Estados Unidos, berço da profissão, demarcações estereotipadas e incoerência quanto à sua atuação, pelo menos 
no campo da literatura ficcional. Ao elucidarmos as relações diretas ou indiretas entre literatura e sociedade, depreendemos que qualquer pessoa que leia o livro e que desconheça as Relações Públicas pode formar opiniões errôneas sobre esse campo da Comunicação Social. Interessante sublinhar que A Janela de Overton é de autoria de Glenn Beck, escritor eleito como autor de best-sellers nos Estados Unidos, cujos livros são amplamente difundidos.

De todo modo, ao retomarmos um dos objetivos específicos desta pesquisa - estimular o aprendizado sobre as Relações Públicas a partir de distintos suportes de conhecimento, como as obras literárias - concluímos que a A Janela de Overton revela-se como uma rica oportunidade para que qualquer aluno, iniciante ou não neste campo, possa aprender de forma lúdica, com uma abordagem diferenciada dos livros teóricos da área. Contudo, faz-se necessário confrontar a ficção com o corpo teórico, analisando e pontuando as relações entre ambos, para que haja melhor entendimento tanto da obra ficcional, nos seus contextos específicos, quanto do campo das Relações Públicas.

\section{REFERÊNCIAS}

ASSOCIAÇÃO BRASILEIRA DE RELAÇÕES PÚBLICAS. Disponível em http://www2.abrpsp.org. br/index.php/Inicio. Acesso em: 10 jan de 2013.

CÂNDIDO, Antônio. A literatura e a formação do homem. In: DANTAS, Vinícius. Textos de intervenção. São Paulo: Duas Cidades, Ed. 34, 2002.

CÂNDIDO, Antonio. Literatura e sociedade. 7. ed. São Paulo: Ed. Nacional, 1985.

EAGLETON, Terry. Teoria da Literatura: uma Introdução. $5^{\text {a }}$ edição. Coleção Biblioteca Universal. São Paulo: Editora Martins Fontes, 1983.

FERRARI, Maria A. Relações públicas contemporâneas: a cultura e os valores organizacionais como fundamentos para a estratégia da comunicação. In: KUNSCH, Margarida M. K. (org.). História, teorias e estratégias nas organizações contemporâneas. São Paulo: Saraiva, 2009 .

FORTES, Waldyr G. Relações públicas: processo, funções, tecnologia e estratégias. São Paulo: Summus, 2003.

FRANÇA, Fábio. Públicos: como identificá-los em uma nova visão estratégica. São Caetano do Sul: Difusão, 2004.

GRUNIG, James E. A função das relações públicas na administração e sua contribuição para a efetividade organizacional e societal. In: Comunicação \& Sociedade, Programa de Pós-Graduação em Comunicação Social, Universidade Metodista de São Paulo, n. 39, 2003, p. 67-92. 
. Teoria Geral de Excelência em Relações Públicas. In: GRUNIG, James E. ; FERRARI, Maria A. ; FRANÇA, Fábio. Relações Públicas: teoria, contexto e relacionamentos. 2 ed. São Caetano do Sul: Difusão, 2011a.

. Relações públicas nos processos de gestão estratégica. In: GRUNING, James E.; FERRARI, Maria A.; FRANÇA, Fábio. Relações Públicas: teoria, contexto e relacionamentos. 2 ed. São Caetano do Sul: Difusão, 2011b.

KUNSCH, Luiz W. Gênese e desenvolvimento do campo profissional e acadêmico das relações públicas no Brasil. In: KUNSCH, Margarida M. K. (org.). História, teorias e estratégias nas organizações contemporâneas. São Paulo: Saraiva, 2009.

KUNSCH, Margarida M. K. . Planejamento de relações públicas na comunicação integrada. 4 ed. São Paulo: Summus, 2003.

. (org.). História, teorias e estratégias nas organizações contemporâneas. São Paulo: Saraiva, 2009.

LOPES, Valéria S. C.;GRANDI, Guilherme. Avaliação, mensuração e valoração em relações públicas. In: KUNSCH, Margarida M. K. (org.). História, teorias e estratégias nas organizações contemporâneas. São Paulo: Saraiva, 2009.

MARCHIORI, Marlene. Comunicação Interna: a organização como um sistema de significados compartilhados. In: Marchiori, Marlene (org.). Faces da cultura e da comunicação organizacional. São Caetano do Sul, SP: Difusão Editora, 2006, p. 205-223.

MOURA, Cláudia P. História das Relações Públicas: fragmentos da memória de uma área. Porto Alegre: EDIPUCRS, 2008.

PERUZZO, Cicillia M. K. Da aparência à essência das relações públicas: abordagem na perspectiva da teoria crítica e do modo de produção capitalista. In: KUNSCH, Margarida M. K. (org.). História, teorias e estratégias nas organizações contemporâneas. São Paulo: Saraiva, 2009.

SOUZA, Roberto A. Q. de. Teoria da Literatura. 8a edição. Série Princípios. São Paulo: Editora Ática, 2004.

RECEBIDO EM: 21/05/2013

ACEITO PARA PUBLICAÇÃO: 16/12/2013 


\section{Luíza de Almeida Tavares Guimarães}

Bacharel em Comunicação Social, habilitação Relações Públicas, pela Universidade Católica de Santos, Santos/SP, Brasil.

\section{Wellington Teixeira Lisboa}

Doutorando em Sociologia na Universidade Estadual de Campinas (Unicamp). Mestre em Comunicação e Jornalismo pela Universidade de Coimbra. Docente e pesquisador da Universidade Católica de Santos, Santos/SP, Brasil. Diretor Científico da Associação Brasileira de Relações Públicas, seção São Paulo (ABRP/SP). 